\title{
HES2 wt Allele
}

National Cancer Institute

\section{Source}

National Cancer Institute. HES2 wt Allele. NCI Thesaurus. Code C114518.

Human HES2 wild-type allele is located in the vicinity of 1 p36.31 and is approximately 12 $\mathrm{kb}$ in length. This allele, which encodes transcription factor HES-2 protein, plays a role in transcriptional repression. 